\title{
Craniovertebral junction cord compression due to neurofibroma
}

\author{
Omprakash Prasad, ${ }^{1}$ Nandakishore Bompelli, ${ }^{2}$ Rakesh Reddy, ${ }^{3}$ Pavan Reddy, \\ Anirudda Deshpande ${ }^{5}$
}

\begin{abstract}
${ }^{1}$ Neurology, Sri Sri Neuro Centre, Warangal, India

${ }^{2}$ Internal Medicine, Aditya Hospital, Warangal, India ${ }^{3}$ Department of Medicine, Aditya Hospital, Warangal, India ${ }^{4}$ Radiology, Vijetha Scans and Diagnostics, Warangal, India ${ }^{5}$ Neurology, Vinayaka Neuro Multispecialty Clinic, Warangal, India
\end{abstract}

\section{Correspondence to}

Dr Anirudda Deshpande, dr.anirudda.deshpande@gmail. com

Accepted 2 June 2018

\section{Check for updates}

(C) BMJ Publishing Group Limited [2018]. No commercial re-use. See rights and permissions. Published by BMJ.

\begin{tabular}{l}
\hline To cite: Prasad O, \\
Bompelli N, Reddy R, et al. \\
BMJ Case Rep Published \\
Online First: [please \\
include Day Month Year]. \\
doi:10.1136/bcr-2018- \\
225286
\end{tabular}

\section{DESCRIPTION}

A 26-year-old man with premorbid cutaneous neurofibromatosis presented with history of insidious onset, slowly progressive, bilaterally asymmetrical quadriparesis along with incontinence of urine since 4 weeks. Simultaneous to the onset of motor symptoms, he also complained of paraesthesias in all four limbs. On examination, multiple cutaneous neurofibromas were noticed all over his trunk, abdomen and all the limbs (figure 1). The upper and lower limbs were spastic. Motor power as per Medical Research Council grading was $3 / 5$ in all four limbs. The deep tendon reflexes were brisk. The plantar response on both sides was extensor. The sensory level was clinically around C3/C4 dermatome.

In view of the premorbid neurofibromata, a possibility of compressive cervical myelopathy was thought of. MRI of cervical spine T2-weighted sagittal view and axial view showed a 'dumbbell' shaped extramedullary, extradural lesion compressing the cervical spinal cord at the craniovertebral junction (figures 2 and 3, respectively). The patient was operated and the lesion was confirmed to be a neurofibroma. The patient did not have other clinical features such as axillary freckles, optic nerve glioma, more than five cafe au lait spots, iris hamartomas and sphenoid dysplasia. However, there was a strong family history. The patient's father had similar lesions on his body.

Hence, the patient fulfilled the criteria of diagnosing neurofibromatosis type 1 .

Neurofibromatosis type 1 is an autosomal dominant disorder which may give rise to benign

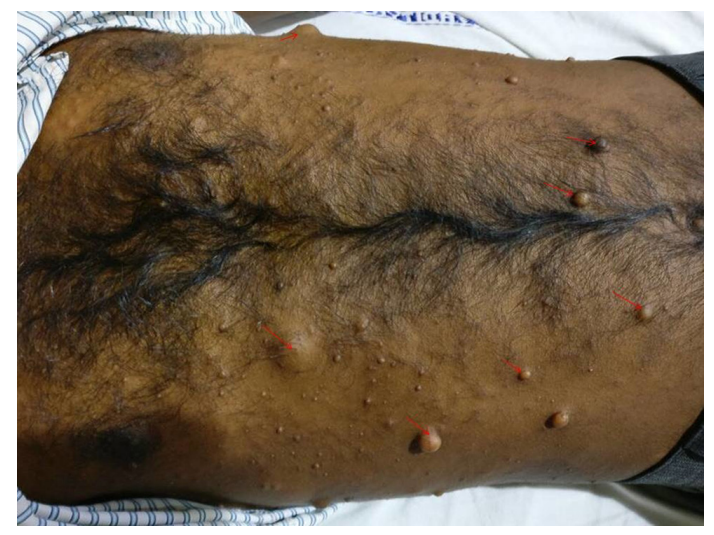

Figure 1 Multiple cutaneous neurofibromas of varying sizes on the lower chest and abdomen (red arrows).

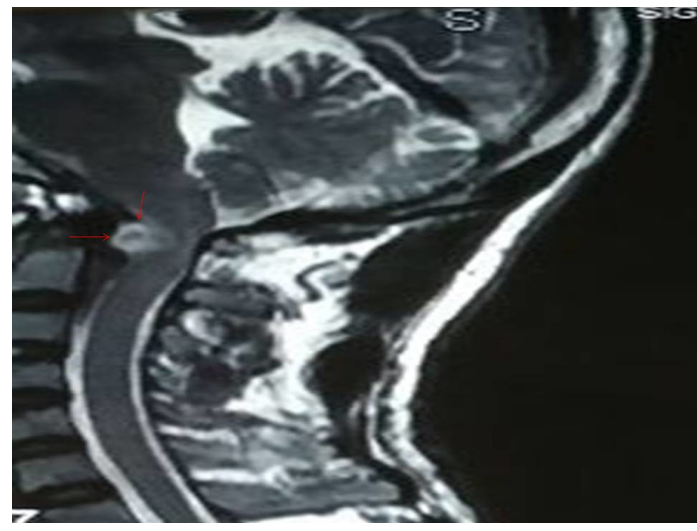

Figure 2 MRI T2-weighted sagittal sequence showing 'dumbbell shaped' lesion (red arrow) compressing the upper cervical cord (yellow arrow) at the craniovertebral junction.

or malignant tumours in affected individuals. Neurofibroma is a benign tumour arising from the endoneurium. They may grow into focal subcutaneous or cutaneous tumours. Seldom, they may manifest as diffuse plexiform neurofibromas that may involve multiple nerve fascicles or plexuses. ${ }^{1}$

The neurofibroma compressing the cervical cord, especially the craniovertebral junction, is rare. There is no age predilection for cervical cord compression due to neurofibroma. C2 nerve roots are most commonly affected. The reason for affinity of neurofibroma for $\mathrm{C} 2$ nerve root has been postulated to the repeated low-grade trauma as it

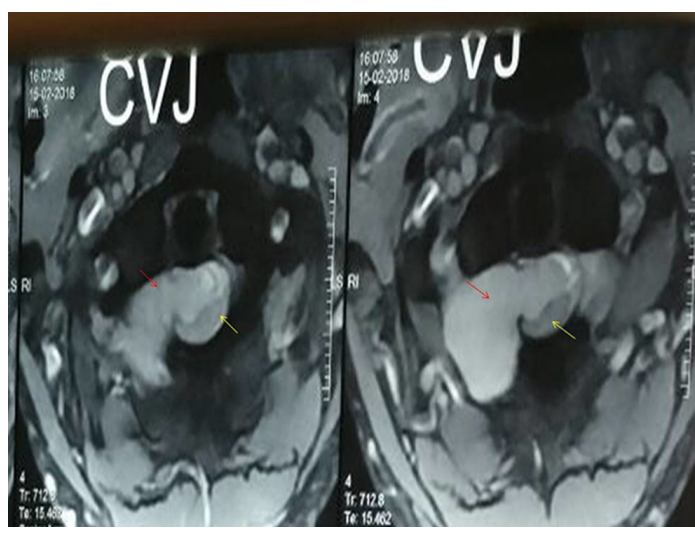

Figure 3 MRI T2-weighted axial view showing 'dumbbell shaped' lesion (red arrow) compressing the upper cervical cord (yellow arrow) at the craniovertebral junction. 
exits the foramen and winds over the superior aspect of lamina of the $\mathrm{C} 2$ vertebra.

Asymptomatic patients with neurofibromatosis type 1 do not require any radiological imaging. Patients developing progressive weakness of all four limbs due to cord compression require urgent neurosurgical intervention. Cord decompression at the level of compression is the preferred neurosurgery procedure. ${ }^{2}$

\section{Learning points}

Neurofibromas are common benign tumours which may manifest as Cranio-vertebral junction anamoly in the form of cord compression rarely.

- C2 region is the most common area involved and is postulated to repeated low grade trauma to C2 nerve root as it winds over the superior aspect of lamina of C2 vertebrae.
Acknowledgements We acknowledge the contribution of our teachers and support of our family members in helping us make this manuscript possible.

Contributors OP and NB made substantial contributions to the conception and design of the work, acquisition, analysis and interpretation of the data. PR and $A D$ were involved in drafting the work and revising it critically for important intellectual content. AD approved the final version to be published.

Funding The authors have not declared a specific grant for this research from any funding agency in the public, commercial or not-for-profit sectors.

Competing interests None declared.

Patient consent Obtained.

Provenance and peer review Not commissioned; externally peer reviewed.

\section{REFERENCES}

1 Thakkar SD, Feigen U, Mautner VF. Spinal tumours in neurofibromatosis type 1: an MRI study of frequency, multiplicity and variety. Neuroradiology 1999:41:625-9.

2 Leonard JR, Ferner RE, Thomas N, et al. Cervical cord compression from plexiform neurofibromas in neurofibromatosis 1. J Neurol Neurosurg Psychiatry 2007:78:1404-6.

Copyright 2018 BMJ Publishing Group. All rights reserved. For permission to reuse any of this content visit

http://group.bmj.com/group/rights-licensing/permissions.

BMJ Case Report Fellows may re-use this article for personal use and teaching without any further permission.

Become a Fellow of BMJ Case Reports today and you can:

- Submit as many cases as you like

- Enjoy fast sympathetic peer review and rapid publication of accepted articles

- Access all the published articles

Re-use any of the published material for personal use and teaching without further permission

For information on Institutional Fellowships contact consortiasales@bmjgroup.com

Visit casereports.bmj.com for more articles like this and to become a Fellow 